\title{
Research Square \\ Factors influencing Adoption of improved bread wheat technologies: a double hurdle approach in Northern Ethiopia
}

Negussie Siyum ( $\square$ negussiese@gmail.com )

Sirinka Agricultural Research Center

Almaz Giziew

Bahir Dar University

Azanaw Abebe

Bahir Dar university

\section{Research Article}

Keywords: Technology adoption, bread wheat, double hurdle, perception

Posted Date: February 25th, 2021

DOl: https://doi.org/10.21203/rs.3.rs-275768/v1

License: (1) This work is licensed under a Creative Commons Attribution 4.0 International License.

Read Full License 


\title{
Factors influencing Adoption of improved bread wheat technologies: a double hurdle approach in Northern Ethiopia
}

\author{
Negussie Siyum $^{1 *}$, Almaz Giziew ${ }^{2}$, Azanaw Abebe $^{2}$ \\ ${ }^{1}$ Sirinka agricultural research center, Woldiya \\ ${ }^{2}$ Bahir Dar university, department of rural development and agricultural extension \\ Corresponding author: Email; negussiese@gmail.com
}

\begin{abstract}
This study was conducted in Meket District, Amhara National Regional State, in northern Ethiopia. Cross-sectional data collected from 214 randomly selected farm households via a structured interview protocol was used for the study. Double-hurdle model was to identify factors affecting the probability of adoption and intensity of use of improved bread wheat varieties and associated technologies in the study area. The first hurdle of the model suggests number of oxen owned by household, mobile phone ownership, education level of the household head and access to extension services significantly affected the probability of any improved bread wheat variety adoption. The intensity of improved bread wheat variety adoption was significantly associated with ownership of main plots, participation in on-farm demonstrations, perception towards shattering problems of local bread wheat varieties, and annual income of household. The findings of this study highlight the importance of economic(such as number of oxen) and institutional(such as access to extension) factors related to agricultural extension and communication, the participation of farmers in on-farm demonstrations, wealth creation and acknowledging farmers' perception regarding improved bread wheat variety attributes. Development interventions should strive to target such economic, institutional, and psychological factors to promote wider adoption of improved bread wheat technologies.
\end{abstract}

Keywords: Technology adoption, bread wheat, double hurdle, perception. 


\section{Background}

Agriculture is one of the biggest components in Ethiopian economy by contributing $34 \%$ of the country's gross domestic product (GDP) and $71 \%$ of employment. Crop production makes up $72 \%$ of the total agricultural GDP, while the livestock sector ejects about $20 \%$ and other areas contribute $8.6 \%$. Cereals (such as wheat, maize, Teff, sorghum, and millet), comprise the major share of crop production as principal staples (ATA, 2018).

The role of new technology to economic growth can only be realized if the new technology is widely diffused and applied by the beneficiaries i.e. farmers. It is also undeniable that, the generation and transfer of agricultural technologies is not an end in itself. The goal of increasing productivity and production of wheat will be realized if and only if the ultimate users, namely farmers, adopt the technologies that are released by research institutions. The reasons for low or non-adoption of new agricultural technologies can be technical, socioeconomic, and/or institutional (Uaiene et al., 2009).

Sub-Saharan Africa, Public agricultural investments have recently shown renewed interest in "package" approaches. These approaches seek to increase farm productivity by addressing issues related to market inefficiencies and limited information simultaneously for a group of complementary inputs. The package approach assumes that the provision of complementary inputs and extension will ensure that the input mix and its application by farmers approach that of controlled agronomic trials, leading to optimal yield outcomes. Since the package approach is a recently grown strategy which is adopted by MoA and ATA, the adoption studies conducted to date are mostly on the basis of a single attribute of the technology might be improved variety, input application and other agronomic practices (Gashaw Tadesse et al., 2016).

There are various studies conducted in the area of adoption specifically in agricultural technologies. According to (D'Souza and Mishra, 2018), years of education, credit access and membership to different clubs significantly affect the adoption of partial conservation. For instance compared with heads of the households with primary education, household heads with secondary education and tertiary education household heads are more likely to adopt partial conservation technologies. 
Another study (Akinola et al., 2010), identified asset owner ship and off farm income as significant factors in determining adoption of balanced nutrient management. Similar with (D'Souza and Mishra, 2018), Akinola et al.(2010) indicated access to credit as determinant factor of adoption. Studies by (Marc et al., 2012; Ghimire et al., 2015 and Abbas et al., 2018) indicated that, adoption of rice varieties significantly affected by extension related variables.

According to Tesfaye Solomon et al. (2014), credit access, household head sex, field day participation, access to all weather roads, access to credit, active family force, district and market distance as being key determinants on the intensity and adoption of use of improved wheat varieties. Hence, the study recommended that emphasize should be given to these variables to improve adoption and intensity of wheat.

Similarly, Manda et al., (2016) argues that education level of the household head has a positive and significant influence on adoption of improved maize varieties. In addition to this, Manda and his colleagues, result shows that access to extension services increases the likelihood of adoption of maize varieties.

The results of adoption study by (Rahman \& Haque, 2013; Sosina Bezu et al., 2014 and Khonje et al., 2015) reveal that education level of the household head has a positive and significant effect on adoption of a given agricultural technologies. In addition to the above, Tariku Bezabih (2012) found out that frequency of contact with extension agents, exposure of mass media and participation on extension events has a positive significant effect on adoption of wheat technologies. According to (Djana Babatima, 2011 and Bayissa Gedefa, 2014), farming experience and education level significantly affect adoption decision of maize and Teff technologies respectively. Katengeza et al. (2012) identified labor endowment, access to rural credit, livestock wealth, access to agricultural extension, farm size and access to off-farm employment as significant factors increasing the likelihood of maize variety adoption.

Findings from Arslan et al. (2014) indicated that, age of the household head and education level significantly increase the intensity of adoption of conservation farming practices while cultivated land per capita decreases the intensity of adoption, resulted from labor constraints. According to Solomon et al. (2014), factors such as, household head sex, credit access, active family force, 
access to all-weather roads, district and market distance had a significant effect on the intensity of use of wheat varieties at different significance levels.

Access to credit positively and significantly influences the adoption and use intensity of balanced nutrient management systems (BNMS). An additional source of credit results an increase of the probability of adoption of BNMS-manure by $11 \%$. Hence, an improvement in access to formal or informal credit will enhance households' technology adoption according to the findings of this study. According to Katengeza et al. (2012), the intensity of maize adoption was found to be negatively related to livestock wealth and fertilizer use.

The findings of Aman Tufa and Tewodros Assefa (2016) indicated that age, farm experience, oxen, membership of cooperative, distance to all weather roads and annual income significantly affect adoption of Barley intensity. According to Abiro Tigabie et al. (2013), social participation and total farm size affected malt barley technology adoption negatively and significantly.

Considerable studies have been conducted on the adoption of agricultural technologies in different parts of the world as well as in our country Ethiopia, and most significantly on identifying factors affecting the adoption of agricultural technologies. However, most of the literatures were based on a single component of the technology (mostly improved variety) than the packages of the technology. Specifically in the study area where the current study was conducted, no empirical research on the adoption of bread wheat has been conducted. Thus, with the pursuit of filling the gaps identified in the above problem statements, the current study on " factors influencing adoption of bread wheat technologies" was conducted.

\section{Methods}

\section{Research design and study area}

The study is based on the cross sectional data collected from smallholder wheat producer famers. The empirical data comes from the farming households residing in the northern part of Ethiopia namely, Meket district. This district was selected primarily because of its presence mandate area of Sirinka Agricultural research center's agricultural technology development, multiplication and dissemination activities. 
The study area, Meket is one of the districts in the Amhara Region of Ethiopia. Meket district consists of 34 rural kebeles (Meket District Office of Agriculture, 2018).

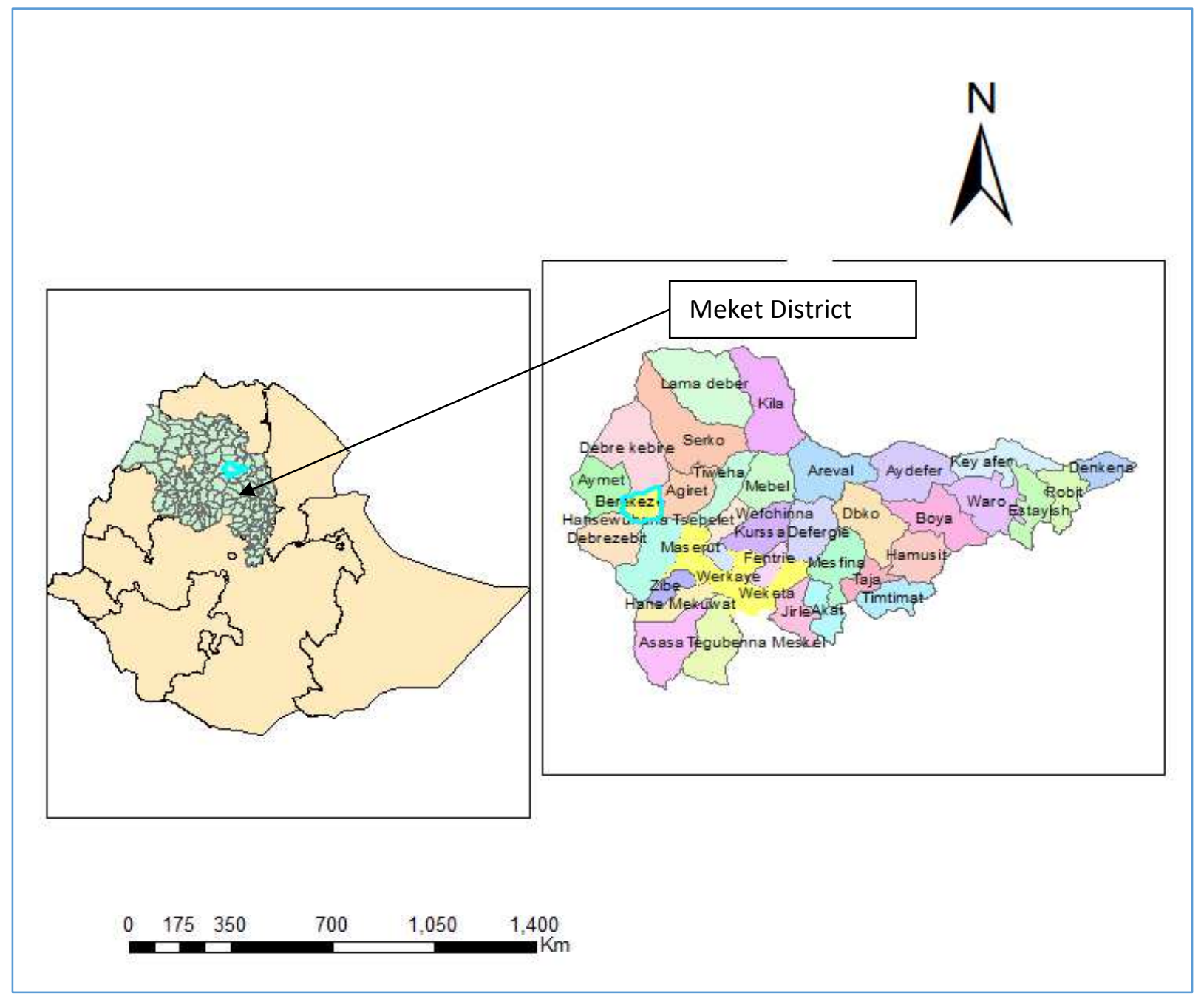

Figure 1 Location map of the study area

Source: CSA, 2011

\section{Sampling design and procedure}

Meket district was one of the intervention sites where bread wheat technology generation, multiplication and promotion conducted. In relation to technology generation and promotion, Sirinka agricultural research center has released and promoted various bread and durum wheat varieties at large scale clustered farms in the district. 
Multi stage sampling technique was employed to select sample households for this study. Meket district has 34 rural administrative kebeles (Meket District Agricultural Office, 2018). From these, 15 of them were identified as potential bread wheat producer kebeles for selecting sample kebeles. Then, four sample kebeles were randomly selected for the study. Finally, sample respondents were selected using systematic random sampling technique. The number of respondents in each kebele was determined by proportionate to size.

Bread wheat grower households in the selected kebeles were used as the sampling frame and the sampling units were the household heads. Hence, based on the type of sampling design, the sample size for this study was determined based on the following formula given by Yamane (1967) as follows:

$\mathrm{n}=\frac{N}{1+N(e)^{2}}$ Equation 1

Where $\mathrm{n}$ is the sample size for the study, $\mathrm{N}$ is the population of interest (wheat grower farmers in the production year 2017/18) which is 4022, e is the precision level which will be 0.07 in this study due to the fact that the population in the study area is relatively homogeneous in the socioeconomic set up. The formula is valid for $95 \%$ confidence level. Based on the above formula 194 sample respondents were selected randomly. According to Israel (2012), it is common to add $10 \%$ of the selected sample for compensating absentees of contact of respondents; hence, 214 samples were selected. The sample size for each kebele was determined based on their proportion to total share of households residing in each kebele.

Table 1. Distribution of sample respondents among selected kebeles

\begin{tabular}{cccccc}
\hline & Kebele & Name & $\begin{array}{c}\text { Number of bread wheat } \\
\text { Growers in 2017/18 }\end{array}$ & $\begin{array}{c}\text { Number of Samples } \\
\text { selected(Using PPS) }\end{array}$ & Share (\%) \\
\hline 1 & 029 & Warkaye & 1212 & 65 & 30.37 \\
2 & 021 & Maserut & 1066 & 57 & 26.63 \\
3 & 028 & Weketa & 966 & 51 & 23.83 \\
4 & 017 & Berekeza & 778 & 41 & 19.15 \\
\multicolumn{2}{c}{ Total } & 4022 & 214 & 100 \\
\hline
\end{tabular}

Source: Own survey, 2019 


\section{Data collection}

Cross-sectional data were used for meeting the objective of this study. The data were collected both from primary and secondary sources. Primary data were collected from the sample farmers using structured questionnaire about bread wheat production, input utilization and demographic characteristics of the household. Secondary data were collected from published documents as, books, proceedings and journals and unpublished documents like annual reports of different organizations. Before the formal data collection, the questionnaire was pretested for further finetuning. In addition, orientation was given for enumerators to have a common understanding regarding the data collection instrument. Finally, the questionnaire was administered by trained researchers of Sirinka agricultural research center in close supervision of the researcher.

\section{Methods of Data Analysis}

In order to describe the overall wheat production status with respect to the desired characteristics, descriptive statistics such as mean, standard deviation, percentages and graphs were used. Furthermore, test statistics such as t-test for continuous variables and chi-square $\left(\chi^{2}\right)$ test for dummy/discrete variables were employed to compare means of socioeconomic characteristics among improved bread wheat technology adopters and non-adopters. Spearman's correlation was also used to test whether there exists significant correlation between categorical variables and intensity of adoption. One way ANOVA was employed for testing the overall mean differences among bread wheat technology adoption categories.

Adoption status of improved bread wheat technologies: Various econometric models have been employed to study the adoption behavior of farmers and to identify the key factors of technology adoption. The econometric specification largely depends on the objectives of the study and the type of data available. In most cases, data are collected on whether a given technology has been adopted or not, without considering additional information on the constraints some producers might face in accessing the technology. One of the most applied methods for modeling technology adoption behavior is the Tobit model. This model assumes that farmers demanding modern inputs have unconstrained access to the technology. However, in situations where input supply systems are underdeveloped, this is often untenable, as farmers 
demanding to apply fertilizer or improved seeds often face input access constraints. The Tobit specification has no mechanism to differentiate households with a constrained positive demand for the new technology from those with unconstrained positive demand, and assumes that a household not adopting the technology is making a rational decision (Yu et al., 2011). Hence, for access constraints to inputs, the Tobit model yields inconsistent parameter estimates (Croppenstedt et al., 2003).

The determinants of bread wheat technology adoption was estimated using double hurdle model because it was assumed that the rate of adoption and intensity of adoption will be affected by different set of factors at different levels. Moreover, it is assumed that the two decisions will be made separately.

The double hurdle model was used to identify factors affecting the probability and intensity of use of an improved bread wheat technology. The double hurdle model is a model in which two separate stochastic processes determine the decision to adopt and the intensity of use of a technology.

Assuming that many Ethiopian farmers have constraints in accessing inputs like fertilizer and improved seed varieties, the double hurdle (DH) model (Cragg, 1971) is a useful and proper approach to analyze technology adoption under constrained access to agricultural inputs. The DH model examines technology adoption in two steps. In the first stage, the farmer decides whether to participate in the fertilizer or other input market. If he/she chooses to participate, then the next step is to decide the quantity to purchase ( $\mathrm{Yu}$ et al., 2011). In this model, the zero values in the dependent variable representing non adoption of the technology could result either from households that decided not to adopt the technology or households that have the willingness to adopt but are not able to do so due to reasons not embodied in the Tobit framework (for example, the non-availability of inputs discussed above). In other words, the DH model allows us to separate the sample of farming households into three groups: households applying fertilizer (or improved seed), households wanting to adopt but reporting no positive application, and households choosing not to adopt. Hence, using the DH model to incorporate this additional information allows us to obtain more efficient and consistent estimates of technology become inconsistent (Amemiya and Powell, 1981; Arabmazar and Schmidt 1981, 1982). 
$\mathrm{Dh}_{\mathrm{i}}=1 \ldots$ if $\mathrm{dh}_{\mathrm{i}}^{*}>0$.

Equation 2

$\mathrm{Dh}_{\mathrm{i}}=0 \ldots$ if $\mathrm{dh}_{\mathrm{i}}^{*}<=0$

Equation 3

$\mathrm{Dh}_{\mathrm{i}}^{*}=\alpha^{*} \mathrm{Z}_{\mathrm{i}}+\mathrm{U}_{\mathrm{i}}$

Equation 4

Where: $\mathrm{dh}_{\mathrm{i}} *$ is a latent variable and $\mathrm{DH}$ takes the value 1 if a farmer adopts improved bread wheat technology and zero otherwise, $\mathrm{Z}$ is a vector of household socioeconomic and institutional characteristics and $\alpha$ is a vector of parameters. The level of adoption (Y) decision has an equation:

$\mathrm{Y}_{\mathrm{i}}=\mathrm{Y}_{\mathrm{i}}^{*}$--- if $\mathrm{Y}_{\mathrm{i}}^{*}>0$--- and---- $\mathrm{DH}_{\mathrm{i}}^{*}>0$ Equation 5

$Y_{i}=0$----otherwise

$\mathrm{Y}_{\mathrm{i}}^{*}=\beta^{\prime} \mathrm{X}_{\mathrm{i}}+\mathrm{V}_{\mathrm{i}}$ Equation 6

Where $Y_{i}$ is the observed amount of agricultural technologies, $\mathrm{X}_{\mathrm{i}}$ is a vector of household socioeconomic and institutional characteristics and $\beta_{\mathrm{i}}$ is a vector of parameter.

The log-likelihood function for the double hurdle model is:

$\log \mathrm{L}=\sum \operatorname{Ln}\left[1-\Phi\left(\alpha z i\left(\frac{\beta X i}{\sigma}\right)\right)\right]+\sum \ln \left[\Phi(\alpha z i *) \frac{1}{\sigma} \Phi\left(\frac{Y i-\beta X i}{\sigma}\right)\right]$ Equation 7

Under the assumption of the independency between the error terms $V_{i}$ and $U_{i}$, the double hurdle model is equivalent to a combination of Probit model (1) and the truncated regression model (2) (Greene, 2003).

Whether estimations are obtained simultaneously or one regression at a time, the results will be identical because of the separability of Cragg's likelihood function. That is, while using craggit makes estimation more coherent, it will not change results. The primary benefit of using craggit is its ability to facilitate post estimation analysis and interpretation (Burke, 2009). However, for this study craggit command was employed to estimate the model. Hence, both the probability and intensity of adoption were estimated via a single command.

Double-hurdle model involves two distinct decisions: the participation decision (whether to adopt bread wheat technologies) and the level of participation (the extent of use of bread wheat technologies). The type of association between these decisions and the specifications of the error terms determine the likelihood function to be estimated. Hence, if an individual makes both decisions separately, the two decisions are modeled independently; or if both decisions are made simultaneously, they are modeled jointly; or if one decision is made first and affects the other 
one, they are modeled sequentially (Martínez, 2006). The resulting models are called the independence, the dependence and the dominance models, respectively.

Levels of adoption of improved bread wheat technology: In order to estimate the level of adoption of improved bread wheat technology (improved variety, row planting, recommended chemical fertilizer application and herbicide/insecticide), adoption index was employed using the following formula.

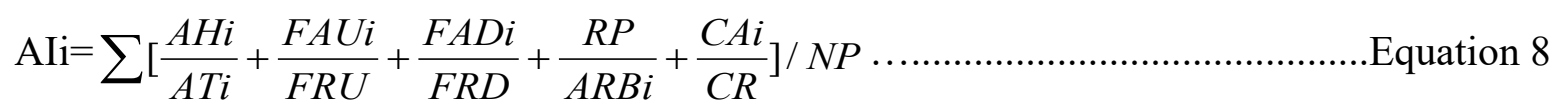

Where: $\mathrm{AIi}=$ Adoption index

$\mathrm{AHi}=$ Area under improved variety of bread wheat of the $i^{\text {th }}$ farmer

$\mathrm{AT} i=$ Total area allocated for bread wheat production (improved variety + local, if any of the $i^{\text {th }}$ farmer

$\mathrm{FAUi}=$ Amount of urea fertilizer applied per unit area of land in the cultivation of bread wheat by $\mathrm{i}^{\text {th }}$ farmer

$\mathrm{FR}_{\mathrm{U}}=$ Amount of Urea fertilizer recommended for application per unit of area in the cultivation of bread wheat $(100 \mathrm{~kg} / \mathrm{ha})$

$\mathrm{FA}_{\mathbf{D}}=$ Amount of NPS fertilizer applied per unit area of land in the cultivation of bread wheat by $\mathrm{i}^{\text {th }}$ farmer

$\mathrm{FR}_{\mathrm{D}}=$ Amount of NPS fertilizer recommended for application per unit of area in the cultivation of bread wheat $(100 \mathrm{~kg} / \mathrm{ha})$

$\mathrm{RP}=$ Area under row planting of bread wheat

$\mathrm{ARBi}=$ Total area of bread wheat (both row planting and broadcasting if any)

$\mathrm{HA}_{\mathrm{i}}=$ Amount of Herbicide Applied per unit of area of $i^{\text {th }}$ farmer

$\mathrm{CR}=$ Amount of herbicide Recommended for application per unit of area, $\mathrm{i}^{\text {th }}$ farmer $\mathrm{NP}=$ Number of practices 


\section{Determinants of bread wheat technology adoption}

The results for the determinants of bread wheat technology has a binary nature and hence estimated by the Probit model (the first hurdle or tier one) is displayed in Table 2. The Wald chisquare value of 30.68 is statistically significant at $1 \%$ indicating that the explanatory variables in model jointly explain both the probability of adoption and intensity of adoption. There is no theoretical guidance as to which variable to include in each hurdle, hence an attempt was made to include a number of economic and perception variables in both hurdles.

Turning to the estimation results, coefficients in the first hurdle (tier1) indicate how a given decision variable affects the likelihood (probability) to adopt improved bread wheat technology. Those in the second hurdle (tier2) indicate how decision variables influence the intensity of bread wheat technology adoption. In the estimation process, 24 explanatory variables were included in the two hurdles (Tier 1 and Tier 2) (Table 2).

The decision to adopt improved bread wheat technology is significantly determined by five of the 12 explanatory variables. The result of the first hurdle (Probit Model) indicates that, number of oxen owned by household, mobile phone ownership, livestock ownership( measured in TLU), Education level of the household head (measured in years of schooling) and number of extension contact significantly determined it. Significant variables determining the decision to adopt bread wheat technologies are well distributed over four categories; household characteristics (education level), asset ownership (number of oxen, livestock ownership and mobile phone ownership), institutional variables (extension contact) and varietal perception.

Oxen based farming is commonly practiced in the study area so that oxen (the number of oxen owned) is included as a separate explanatory variable in the model. The coefficient of this variable is statistically significant at $5 \%$ significance level and has a positive effect on the probability to adopt improved bread wheat technologies. Furthermore, its marginal effect implies that an increase in number of oxen increases the likelihood of adopting improved bread wheat technologies by 3.9\%. This result is consistent with the findings of (Chilot Yirga et al.,2013; Aman Tufa and Tewdros Tefera, 2016) who found out positive and significant effect of number of oxen on adoption. 
Access to information was expected to positively affect the likelihood of adopting improved agricultural technologies. In this study, the effect is captured by ownership of mobile phone. As expected mobile phone ownership has a positive effect for bread wheat technology adoption and statistically significant at $1 \%$ significance level. The marginal effect also reveals that possessing mobile phone increases the probability of bread wheat technology adoption by $12.5 \%$. Along with the development of information communication technology and the needs, mobile phone as an instrument or medium of information communication is widely used by farmers. Hence, farmers with cell phones can support the extension communication channel and access information easily. Thus, communication via mobile phone might contribute for facilitating advisory services with development agents. This result is consistent with the study by Solomon Asfaw et al., (2011) who find out that ownership of mobile phone positively and significantly affected agricultural technology adoption.

Livestock wealth also positively influences the adoption of bread wheat technologies. The coefficient of livestock ownership is statistically significant at $5 \%$ level of significance and has positive effect on the probability to adopt improved bread wheat technologies. An increase in livestock ownership by one TLU increases the likelihood of adopting improved bread wheat technologies by $5.5 \%$. This might be due to the reason that in Ethiopia farm machineries are not yet widely used by smallholder farmers (except large-scale investment farms) in this case livestock are the major source of drafting and traction power. Moreover, livestock are indicators of wealth in the farming community. This result is consistent with various adoption studies such as Njane (2007) and Katengeza et al. (2012).

The probability of improved bread wheat adoption was influenced positively and significantly by education level of household head at 10\% significance level. The result implied that educated household heads were more likely to adopt improved bread wheat technology. More specifically an increase in years of schooling increases the probability of bread wheat adoption by $1.1 \%$. This result is in agreement with Tariku Bezabih (2012) who find out a positive and significant effect of education and wheat variety adoption. Education level was included in both hurdles of the model. While the coefficient of this variable was significant in the first hurdle (probability equation), it was not significant in the second hurdle (intensity) of adoption. The result might be an indication that the two decisions (Adoption and intensity of adoption) can be affected by 
different set of explanatory variables. Once the education affects the decision to adopt, the decision on the intensity might not be influenced by education level.

Frequency of extension contact positively affects household's probability of bread wheat technology adoption at 5\% level of significance. In addition, the marginal effect of this variable reveals that an increase in frequency of extension contact increases the probability of adoption by $4.96 \%$. The result indicates that farmers with frequent extension visit are more likely to adopt improved bread wheat technologies. This result is in agreement with (Simtowe et al., 2011; Sodjinou et al., 2011; Akalu Teshome and Ermias Abate, 2013; and Chandio and Yuansheng, 2018).

\section{Determinants of intensity of adoption of bread wheat technologies}

The decision to adopt improved bread wheat technology is significantly determined by four of the 12 explanatory variables. As shown in Table 2 below, the result of the second hurdle (Tier 2) indicates that the variables such as, ownership of main plots (Ownership), participation on onfarm demonstrations (Partondemon), perception towards shattering problem of bread wheat varieties (Shateringproblem) and annual income (logAnnualincome) are the significant determinants for adoption intensity of bread wheat technologies.

Ownership of land by title (Ownership) negatively influenced adoption intensity of bread wheat technologies and this variable was statistically significant at $10 \%$. Ownership of land decreases intensity of adoption by $4 \%$, indicating that farmers cultivating bread wheat on renting are less reluctant to use improved bread wheat technologies than those possessing land. The implication of the result might be related to the fact that farmers renting land for bread wheat have to use intensive technologies to cover production costs related to land rent, labor and fertilizer. Since farmers are expected to reap significant benefits in the short run from bread wheat technology adoption, they tend to invest on agricultural intensification.

Participation on on-farm demonstration (proxy for access to agricultural extension services) positively and significantly affects intensity of bread wheat technology adoption at $5 \%$ level of significance. Participation of farmers on on-farm demonstration increases the level of adoption by $6.72 \%$. The result suggests that, on farm demonstrations are means of learning by doing 
which enable farmers to develop confidence on the given technology. In addition, demonstration plots will create the opportunity for experience sharing among invited and host farmers of the demonstration plots. This result is consistent with Yigezu Atnafe et al. (2018) who find out that both hosting and involvement on-farm demonstration trials decreases the duration to adoption by $36.5 \%$.

Farmers' perception towards shattering problem negatively affected intensity of bread wheat adoption at 5\% significance level. The result implying that, farmers perceiving negative advantage about the improved variety towards shattering problem would allocate lower parcel of land for bread wheat production. This result is consistent with the theory of diffusion of innovation by Rogers (1983). According Rogers (1983), "The greater the perceived relative advantage of an innovation, the more rapid its rate of adoption will be." The degree to which the farmer perceives the technology as important matters how much to allocate his/her land for the introduced technology.

As expected, the coefficient of annual income is positive and significant at $10 \%$ significance level. Accordingly, an increase in household annual income by one Birr would lead to an increase in the intensity of bread wheat technology adoption by $2.49 \%$. This could happen because a household with necessary annual income could not be financially constrained and prohibited from the timely use of improved bread wheat technology packages. This result is consistent with the findings of (Hassen Beshir et al., 2012 ; Aman Tufa and Tewodros Tefera, 2016 and Degefu Kebede et al., 2017). 
Table 2. Estimates of double hurdle model for adoption of bread wheat technologies

Double Hurdle

\begin{tabular}{|c|c|c|c|c|}
\hline \multicolumn{3}{|c|}{ First hurdle(Tier 1) } & \multicolumn{2}{|c|}{ Second hurdle (Tier 2) } \\
\hline Variables & Coefficient & $\begin{array}{c}\text { Marginal } \\
\text { Effect }\end{array}$ & Variable & Coefficient \\
\hline Fertistat & $0.1547(0.3679)$ & 0.0178 & Fertistat & $0.06234(0.04057)$ \\
\hline Ownership & $-0.0659(0.3628)$ & -0.0080 & Ownership & $-0.07059 *(0.04033)$ \\
\hline Corironsheet & $0.2383(0.2182)$ & 0.0300 & Edulevel & $0.00306(0.00557)$ \\
\hline Marketinfo & $0.1912(0.2538)$ & 0.0239 & Age & $0.00810(0.00929)$ \\
\hline Oxen_no & $0.3123 * *(0.1585)$ & 0.0394 & Agesquare & $-0.00005(0.00008)$ \\
\hline Oxplsetowned & $0.1368(0.1935)$ & 0.0172 & Plot_No & $0.01899(0.01314)$ \\
\hline Mobileowned & $0.7387 * * *(0.2767)$ & 0.1247 & Partondemo & $0.06727 * *(0.03058)$ \\
\hline Offfarm & $-0.4377(0.2756)$ & -0.0518 & Marketable & $-0.02957(0.02369)$ \\
\hline TLU & $0.4323 * *(0.1940)$ & 0.0545 & Credit use & $0.00902(0.02971)$ \\
\hline Edulevel & $0.0868 * *(0.0505)$ & 0.0109 & Yieldbetter & $0.01612(0.02199)$ \\
\hline Social & $0.0693(0.0738)$ & 0.0087 & Shateringpr & $-0.00533 * *(0.00298)$ \\
\hline EXTENSION & $0.3935 * *(0.1633)$ & 0.0496 & LogAnincm & $0.02494 *(0.01473)$ \\
\hline Constant & $-1.0275(0.5924)$ & & $0.29730(0.3$ & 122) \\
\hline Sigma & $0.1989 * * *(0.0080)$ & & & \\
\hline
\end{tabular}

Log pseudolikelihood $=-22.882145 \quad$ Prob $>$ chi $2=0.0022$

Numbers in the parenthesis are robust standard errors 


\section{Conclusions and Recommendations}

Descriptive results of the study revealed that, there exists a significant variation among adopters and non-adopters in relation to education level, age, livestock ownership, mobile phone ownership and number of oxen owned. Improved bread wheat varieties such as Dinknesh, Digalu, Denda, and Kakaba predominantly grown in the study area. On the other hand, the adoption rate of bread wheat technology was found to be $88.78 \%$ whereas the intensity of bread wheat technology package in the study area was about $67 \%$.

The first tier of double hurdle model analysis indicated that number of oxen, mobile phone ownership, livestock ownership, education level of the household head and extension contact significantly determine the adoption of bread wheat. The second tier of double hurdle model indicates that, ownership of wheat plots, participation on on-farm demonstrations, perception towards shattering problem of bread wheat varieties and annual income significantly determine adoption intensity of bread wheat technology. Farmers' perception towards the perceived relative advantages demonstrated that; marketability, early maturity, better yield and color were perceived to be the most important technology attributes for bread wheat varieties by farmers. The low adoption rate and intensity of row planting was related to extra labor required compared to broadcast planting.

Based on the results of this study, it is suggested that the adoption of improved bread wheat technologies could be increased by raising farm household asset formation, providing frequent extension visit, improving agricultural information system, enhancing participation on agricultural events such as on farm demonstrations and field days. Moreover, bread wheat variety development strategies should be directed in alignment with farmers' perception.

Apart from grain yield, researchers in the area of bread wheat varietal development should consider farmers' varietal perception towards marketability, seed color, food (bread) quality and shattering problem. Increasing the efficiency of row planting related to labor could increase the adoption rate of the technology. Hence, measures related to improving labor efficiency of farm implements should be developed and promoted in the study area. 


\section{DECLARATIONS}

\section{Authors' contributions}

NS carried out the study, worked out almost all of the technical details, performed the data analysis and wrote the manuscript. AG contributed to the design and implementation of the research, to the analysis of the results and to the writing of the manuscript. AA advised the coauthor from proposal writing to the main conceptual ideas and proof outline. All authors read and approved the final manuscript.

\section{Aknowledgements}

The authors would like to thank Amhara Agricultural Research Institute for financing the research work. Similarly, we are grateful to the respondent farmers who have spent their precious time to respond attentively to questionnaire. Moreover, the agricultural office of the district had direct and indirect contribution for the successfulness of the survey work.

\section{Competing interests}

The authors declare that they have no competing interests

\section{Availability of data and materials}

Datasets used for analysis can be received up on the request of the corresponding author

\section{Consent for publication}

Not Applicable

\section{Funding}

Data collection was supported by Amhara Agricultural Research Institute 


\section{Consent to participate}

Date:

Interviewer:

Any research work should respect certain ethical standards. Accordingly, this research entitled "Determinants of Adoption of Improved Bread Wheat Technologies in East Amhara Region, Ethiopia" had been carefully guided with research ethics. The research process was begun by asking the willingness of the participants whether they agree or not to participate in the interview. The purpose of the study was carefully informed for the interviewee. Moreover, the participants were informed as they have full right to discontinue or refuse to participate in the need assessment study. In addition, the participants were informed to freely answer in the questionnaire or to be free in expressing their experience as the information they provide would kept confidential. In order to secure the identity and to protect the confidentiality of the participants, the respondents were not forced to disclose their names at the questionnaire or during the interview. In the report document, anonymity of respondents was kept by using code.

\section{Consent Form}

\section{Informed Consent For Farmers}

Hello. Thank you for taking your time to talk to me. My name is and I am working with a research team of Sirinka

Agricultural Research Center on "Determinants of Adoption of Improved Bread Wheat Technologies in East Amhara Region, Ethiopia”. We are collecting data and I would like to ask you questions about yourself and your life experience. Your participation is very important to learn about bread wheat technology adoption and it also very helpful for the programmers and planners to design appropriate intervention. Your name will not be written in this form and the information you give are kept confidential. You will not get any harm being participating in this research. Do you agree to participate in the study?

$1=$ Yes

$2=\mathrm{NO}($ End the interview) 


\section{Authors' details}

${ }^{1}$ Socioeconomics and Agricultural extension directorate, Sirinka Agricultural Research center P.O.box 74, Sirinka Ethiopia.

${ }^{2}$ Department of Rural Development and Agricultural Extension, Bahir Dar University, Ethiopia 


\section{REFERENCES}

Abebe Atilaw and Lijalem Korbu. 2011. Recent development in seed systems of Ethiopia. Debre zeit agricultural research center, Ethiopia

Abebe Beyene and Menale Kassie. 2015. Speed of adoption of improved maize varieties in Tanzania: an application of duration analysis. Technological Forecasting and Social Change, 96: 298-307. http://dx.doi.org/10.1016/j.techfore.2015.04.007.

Abiro Tigabie, Chilot Yirga and Jema Haji. 2013. Determinants of Malt Barley Technology Adoption in the case of Oromia, Ethiopia. MSc Thesis, Haramaya University.30 pp.

Ajao A., Ogunniyi L. and Oyedele G. 2013. Agricultural productivity growth and incidence of poverty: an experience from Africa. Journal of Economics and Sustainable Development, 4 (5): 207-215.

Akalu Teshome and Ermias Abate. 2013. Wheat technologies from where to where? The case of east Gojam zone of Amhara region, Ethiopia. Journal of Agricultural Economics and Development, 2 (6): 226-36.

Akhtar K. and Pirzada S. 2014. SWOT analysis of agriculture sector of Pakistan. Journal of Economics and Sustainable Development, 5 (11): 127-34.

Akinola A., Arega Alene, Adeyemo R., Sanogo D., Olanrewaju A. Nwoke C., and Nziguheba G. 2010. Determinants of adoption and intensity of use of balance nutrient management systems technologies in the northern guinea savanna of Nigeria. Quarterly journal of international agriculture, 49 (1): 25-45. https://ageconsearch.umn.edu/record/155541

Alemitu Mulugeta. 2011. Factors Affecting Adoption of Improved Haricot Bean Varieties and Associated Agronomic Practices in Dale Woreda, SNNPRS. MSc Thesis, Hawassa University, Ethiopia. 121 pp.

Almaz Giziew. 2008. Adoption of Chickpea Technology Packages in Ada'a and Akaki Woredas, Eastern Shewa, Ethiopia. MSc Thesis, Haramaya University. 168 pp. 
Aman Tufa and Tewodros Tefera. 2016. Determinants of improved barley adoption intensity in Malga district of Sidama zone, Ethiopia. International Journal of Agricultural Economics, 1 (3): 78-83. https://doi.org/10.11648/j.ijae.20160103.15

Amemiya T. and Powell J. 1981. A comparison of the Box-Cox maximum likelihood estimator and the non-linear two-stage least squares estimator. Journal of Econometrics, 17(3), pp.351-381.

Arabmazar A. and Schmidt P.1981. Further evidence on the robustness of the Tobit estimator to heteroskedasticity. Journal of Econometrics, 17(2), pp.253-258.

Arabmazar A. and Schmidt P. 1982. An investigation of the robustness of the Tobit estimator to non-normality. Econometrica: Journal of the Econometric Society, pp.1055-1063.

Arslan A., McCarthy N., Lipper L., Asfaw S. and Cattaneo A. 2014. Adoption and intensity of adoption of conservation farming practices in Zambia. Agriculture, Ecosystems and Environment, 187:72-86.

Agricultural Transformation of Ethiopia (ATA). 2018. Annual Report

Awotide B., Karimov A. and Diagne A. 2016. Agricultural technology adoption, commercialization and smallholder rice farmers' welfare in rural Nigeria. Agricultural and Food Economics, 4 (1):3

Bayissa Gedefa.2014. A double-hurdle approach to modeling of improved Teff technologies adoption and intensity use: The case of Diga district of East Wollega Zone, Ethiopia. Global Journal of Environmental Research, 8(3): 41-49.

Becerril J. and Abdulai A. 2010. The impact of improved maize varieties on poverty in Mexico: a propensity score matching approach. World Development, 38 (7): 1024-35.

Bekele Hundie., Verkuijl H., Mwangi W. and Tanner D. 2000. Adoption of improved wheat technologies in Adaba and Dodola Woredas of the Bale Highlands, Ethiopia. 
Bekele Shiferaw, Menale Kassie, Moti Jaleta, and Chilot Yirga. 2014. Adoption of improved wheat varieties and impacts on household food security in Ethiopia. Food Policy, 44: 272-84. http://dx.doi.org/10.1016/j.foodpol.2013.09.012

Bekele Shiferaw, Tewodros Kebede and You L. 2008. Technology adoption under seed access constraints and the economic impacts of improved pigeon pea varieties in Tanzania. Agricultural Economics, 39 (3): 309-23.

Burke W. 2009. Fitting and interpreting Cragg's Tobit alternative using Stata. The Stata Journal, 9 (4): 584-92.

Central Statistical Agency (CSA). 2014. Agricultural Sample Survey: Report on Area, Production, and Farm Management. Vol. 5. Addis Ababa, Ethiopia.

Central Statistical Agency (CSA). 2017. Agricultural Sample Survey: Report on Area and Production of Major Crops. Vol. I. Addis Ababa, Ethiopia.

Chandio A. and Yuansheng J. 2018. Determinants of adoption of improved rice varieties in northern Sindh, Pakistan. Rice Science, 25(2): 103-110.

Chiemeke S. and Evwiekpaefe A. 2011. A conceptual framework of a modified unified theory of acceptance and use of technology (UTAUT) model with Nigerian factors in e-commerce adoption. Educational Research, 2: 1719-1726.

Chilot Yirga, Moti Jaleta, Ali Mohammad, Bekele Shiferaw, Groote H., Menale Kassie, and Takele Mebratu. 2013. Analysis of Adoption and Diffusion of Improved Wheat Technologies in Ethiopia. A research report. Ethiopian Institute of Agricultural Research (EIAR). Addis Ababa, Ethiopia. 61pp.

Cragg, J. 1971. Some statistical models for limited dependent variables with application to the demand for durable goods, Econometrica, 39, 829-844.

Croppenstedt A., Mulat Demeke and Meschi, M. 2003. Technology adoption in the presence of constraints: The case of fertilizer demand in Ethiopia. Review of Development Economics, 7(1):58-70. 
Cunguara B. and Darnhofer I. 2011. Assessing the impact of improved agricultural technologies on household income in rural Mozambique. Food Policy, 36 (3): 378-90.

D'Souza A. and Mishra A. 2018a. Adoption and abandonment of partial conservation technologies in developing economies: the case of south Asia. Land Use Policy, 70: 212223. http://dx.doi.org/10.1016/j.landusepol.2017.10.015

D'Souza A. and Mishra A. 2018b. Dynamics of variety change on wheat farms in Pakistan: A Duration Analysis. Land Use Policy, 59: 24-33.

Degefu Kebede, Mengistu Ketema, Nigussie Dechassa and Feyisa Hundessa. 2017. Determinants of adoption of wheat production technology package by smallholder farmers: Evidences from Eastern Ethiopia. Turkish Journal of Agriculture Food Science and Technology, 5 (3): 267-274. doi:10.1016/j.foodpol.2011.03.002

Dooley K. 1999. Towards a holistic model for the diffusion of educational technologies: An integrative review of educational innovation studies. Educational Technology \& Society, 2(4), 35-45.

Dudwick N., Kuehnast K., Jones V. and Woolcock M. 2006. Analyzing Social Capital in Context: A Guide to Using Qualitative Methods and Data. Stock No. 37260. The International Bank for Reconstruction and Development, World Bank, Washington, D.C. $46 \mathrm{pp}$.

Duvel, G. (1969). An interdisciplinary model for behavior analysis and intervention in agricultural extension and rural development. Journal of International Agricultural and Extension Education, 4(3), 55-65.

Ermias Tesfaye. 2013. Adoption of Improved Sorghum and Farmers' Varietal Trait Preference in Kobo district, North Wollo zone, Ethiopia. MSc Thesis, Haramaya University, Ethiopia. 136 pp.

Ethiopian Agricultural Transformation Agency (ATA). 2018. Annual report 2017-18. Addis Ababa, Ethiopia. 
Feder G., Just R. and Zilberman D. 1982. Adoption of Agricultural Innovation in Developing Countries. Working paper 542. The International Bank for Reconstruction and Development, World Bank, Washington, D.C. 84 pp.

Gashaw Tadesse, de Brauw A., Minot N. and Tanguy B. 2014. The Impact of the Use of New Technologies on Farmers Wheat Yield in Ethiopia: Evidence from a Randomized Controlled Trial. A project report: The Consultative Group on International Agricultural Research (CGIAR), International Food Policy Research Institute (IFPRI). Addis Ababa. $31 \mathrm{pp}$.

Ghimire R., Wen-chi H. and Shrestha R. 2015. Factors affecting adoption of improved rice varieties among rural farm households in central Nepal. Rice Science, 22 (1): 35-43.

Greene W. 2003. Econometric Analysis. Fifth edition, Pearson Education, Inc., Upper Saddle River, New Jersey, USA

Gumataw Abebe, Bijman J., Pascucci S. and Omta O. 2013. Adoption of improved potato varieties in Ethiopia: The role of agricultural knowledge and innovation system and smallholder farmers' quality assessment. Agricultural Systems, 122: 22-32.

Hailu Beyene. 2008. Adoption of Improved Teff and Wheat Production Technologies in CropLivestock Mixed Systems in Northern and Western Shewa Zones of Ethiopia. PhD Thesis. University of Pretoria, South Africa. 193 pp.

Hassen Beshir, Bezabih Emana, Belay Kassa and Jema Haji. 2012. Determinants of Improved Wheat Seed Technology Adoption: The Case of Smallholder Farmers in North Eastern Highlands of Ethiopia. Proceedings of the 13th Annual Conference of the Agricultural Economics Society of Ethiopia, Addis Ababa. PP. 57-78.

Hassen Beshir. 2014. Factors affecting the adoption and intensity of use of improved forages in northeast highlands of Ethiopia. American Journal of Experimental Agriculture, 4 (1): $12-27$. 
Hunecke C., Engler A., Jara-Rojas R. and Poortvliet P. 2017. Understanding the role of social capital in adoption decisions: An application to irrigation technology. Agricultural Systems, 153: 221-231.

Idowu O. 2005. Farmers' perception of agricultural extension agents' characteristics as factors for enhancing adult learning in Mezam division of northwest province of Cameroon. Australian Journal of Adult Learning, 45 (2): 224-237.

Israel D. 2012. Determining Sample Size. Second edition. PEOD6. University of Florida. Gainesville. (http://edis.ifas.ufl.edu/pd006).

Jemal Assen, Berhan Tegegne, Dessalegn Getu, Negussie Siyum and Daniel Lemlem. 2014. PreScaling up of improved bread wheat technology packages through developing Local seed system at Meket and Wadla districts, North Wollo, Ethiopia. Unpublished.

Katengeza S., Mangisoni J., Girma Tesfahun., Sutcliffe C., Langyintuo A., La Rovere R. and Mwangi W. 2012. Drivers of improved maize variety adoption in drought prone areas of Malawi. Journal of Development and Agricultural Economics 4 (14): 393-403.

Khonje M., Manda J., Arega Alene and Minale Kassie. 2015. Analysis of adoption and impacts of improved maize varieties in eastern Zambia. World Development, 66: 695-706. http://dx.doi.org/10.1016/j.worlddev.2014.09.008

Kinyangi A. 2014. Factors Influencing Adoption of Agricultural Technology among Smallholder Farmers in Kakamega North Sub County, Kenya. M.Sc. Thesis, University of Nairobi, Kenya. 87 pp.

Lambrecht I., Vanlauwe B., Merckx R. and Maertens M. 2014. Understanding the process of agricultural technology adoption: mineral fertilizer in eastern DR. Congo. World Development, 59: 132-46. http://dx.doi.org/101016./j.worlddev.2014.01

Le K. and Tam V. 2007. A survey on effective assessment methods to enhance student learning. Journal of Innovative Education, 5 (1): 1-19. 
Lulit Mitik, Bekele Shiferaw, Sahoo A. and Gbegbelegbe S. 2016. Economy-Wide Impacts of Technological Change in Food Staples in Ethiopia: A Macro-Micro Approach. Working paper 2016-17. International Maize and Wheat Improvement Center (CIMMYT) and Partnership for Economic Policy (PEP), Addis Ababa, Ethiopia.

Macauley H. and Ramadjita T. Cereal Crops: Rice. Maize, Millet, Sorghum, Wheat. Background paper. Feeding Africa. Senegal, Dakar. 36 pp.

MahougbéHounsa A., Godin G., Alihonou E., Valois P. and Girard J. 1993. An application of Ajzen's theory of planned behavior to predict mothers' intention to use oral rehydration therapy in a rural area of Benin. Social Science and Medicine, 37 (2): 253-261.

Manda J., Arega Alene., Gardebroek C., Minale Kassie. 2016. Adoption and impacts of sustainable agricultural practices on maize yields and incomes: evidence from rural zambia. Journal of Agricultural Economics, 67 (1). https://doi.org/10.1

Mariano M., Villano R. and Fleming E. 2012. Factors influencing farmers' adoption of modern rice technologies and good management practices in the Philippines. Agricultural Systems, 110: 41-53. http://dx.doi.org/10.1016/j.agsy.2012.03

Martinez-Espineira R. 2006. A Box-Cox Double-hurdle model of wildlife valuation: The Citizen's Perspective. Ecological Economics, 58(1):1192-208.

Mathenge M., Smale M. and Olwande J. 2014. The impacts of hybrid maize seed on the welfare of farming households in Kenya. Food Policy, (44): 262-71.

Mbugua F. 2009. An Analysis of Factors Influencing Adoption of The Recommended Maize Technology's Package in Makuyu Division, Murang'a South District, Kenya. MSc Thesis. Kenyatta University. 113 pp.

Meket District Office of Agriculture. 2018. Annual report of crop and livestock production.unpublished

Menale Kassie, Moti Jaleta, Bekele Shiferaw, Mmbando F. and Mulugeta Mekuria. 2013. Adoption of interrelated sustainable agricultural practices in smallholder systems: 
evidence from rural Tanzania. Technological Forecasting and Social Change, 80 (3): 525-540. http://dx.doi.org/10.1016/j.techfore.2012.08.007

Mengstu Ketema and Degefu Kebede. 2017. Adoption intensity of inorganic fertilizers in maize production: empirical evidence from smallholder farmers in eastern Ethiopia. Journal of Agricultural Science, 9 (5). 124-132. https://doi.org/10.5539/jas.v9n5p124.

Mesfin Fenta. 2017. Adoption of Improved Chickpea Technologies in North Gondar Zone of Ethiopia: The Case of Gondar Zuria. MSc Thesis, University of Gondar, Ethiopia. 117 pp.

Mignouna D. 2011. Adoption and Impact of Improved Agricultural Technologies in Developing Countries: the case of Imazapyr-resistant maize in Western Kenya. PhD diss. Sokoine University of Agriculture, Kenya. 227 pp.

Minot N., Warner J., Solomon Lemma, Leulsegged Kasa, Gashaw Tadesse, and Rashid S. 2015. The Wheat Supply Chain in Ethiopia: Patterns, Trends, and Policy Options. Technical Report July 2015 Washington, DC. International Food Policy Research Institute (IFPRI). DOI: $10.13140 /$ RG.2.1.3408.7285

Mohamad M. and Gombe M. 2017. E-Agriculture revisited a systematic literature review of theories, concept, practices, methods, and future trends. In British Academy of Management Conference Proceedings. British Academy of Management

Mohammed Abinasa, Amsalu Ayana and Geremew Bultosa. 2011. Genetic variability, heritability and trait associations in durum wheat (Triticum turgidum L. var. durum) genotypes. African Journal of Agricultural Research, 6(17): 3972-3979.

Motuma Tura, Dejene Aredo, Wondwossen Tsegaye, La Rovere R., Girma Tesfahun, Mwangi W. and Mwabu G. 2010. Adoption and continued use of improved maize seeds: case study of central Ethiopia. African Journal of Agricultural Research, 5 (17): 2350-58.

Negese Tamirat, Jemal Abafita \& Endeg Tekalegn. 2016. Adoption and Impact of Row Planting of Wheat Crop on Household Livelihood: A Case Study of Duna Woreda in Hadiya Zone, Ethiopia. Unpublished. 
Njane P. 2007. Determinants of Adoption of Improved Wheat Varieties and Fertilizer Use by Small Holder Farmers in Njoro and Kieni West Divisions. MSc Thesis, Egerton University, Kenya. 103 pp.

Obuobisa-Darko E. 2015. Socio-economic determinants of intensity of adoption of cocoa research innovations in Ghana. International Journal of African and Asian Studies, 12: 29-41.

Ott R. and Longnecker M. 2016. An Introduction to Statistical Methods \& Data Analysis. Seventh edition. Boston: Macmillan Publishing Services. Cenveo Publishing Services. www.cengage.com/permissions.

Rabbi F., Ahamad R., Ali S., Chandio A., Ahmad W., Ilyas A. and Din I., 2017. Determinants of commercialization and its impact on the welfare of smallholder rice farmers by using Heckman's two-stage approach. Journal of the Saudi Society of Agricultural Sciences, 18 (2): 224-233. http://dx.doi.org/10.1016/j.j

Rahman M. and Haque Z. 2013. Adoption of selected wheat production technologies in two northern districts of Bangladesh. International Journal of Agricultural Research, Innovation and Technology, 3(1): 5-11. DOI: 10.3329/ijarit.v3i1.16043

Rogers E. 1983. Diffusion of Innovations. Third edition. London: Collier Macmillan Publishers.

Rogers E. 2003. Diffusion of Innovations. Fifth edition. New York: Library of Congress Cataloging-in-Publication Data.

Rogers E. and Kincaid D. 1981. Communication networks: a new paradigm for research. New York: free press.

Rogers E.1962. Diffusion of innovations. New York, USA: Free Press of Glencoe, pp.79-134.

Samaradiwakara G. and Gunawardena C. 2014. Comparison of existing technology acceptance theories and models to suggest a well improved theory/model. International Technical Sciences Journal, 1(1): 21-36. 
Samuel Diro, Misganaw Anteneh, Tegegne Efrem, Asfaw Gutema, Beza Erko, Erge Addisu, and Bezabeh Ali. 2016. Adoption and impacts of dairy production technologies in southwest Ethiopia: The Cases of Jimma and Ilu-Ababora Zones. Journal of Biology, (6)7: 1-12.

Sharma R. and Mishra R. 2014. A review of evolution of theories and models of technology adoption. Indore Management Journal, 6(2): 17-29.

Shimeles Hailu. 2013. The Impact of Disaster Risk Management Interventions in Humanitarian Programs On Household Food Security The Case of East Africa, Ethiopia, Amhara Region, and North Wollo Zone. UNOCHA.

Simtowe F., Minale Kassie, Diagne A., Solomon Asfaw, Bekele Shiferaw, Silim S. and Muange E. 2011. Determinants of agricultural technology adoption: The case of improved pigeon pea varieties in Tanzania. Quarterly Journal of International Agriculture. 50 (4): 325345.

Simtowe F., Solomon Asfaw and Tsedeke Abate. 2016. Determinants of agricultural technology adoption under partial population awareness: The case of Pigeon pea in Malawi. Agricultural and Food Economics, 4: 1-21. DOI 10.1186/s40100-016-0051-z.

Sinafikeh Asrat, Mahmud Yesuf, Carlsson F. and Edilegnaw Wale. 2009. Farmers' Preferences for Crop Variety Traits: Lessons for on-Farm Conservation and Technology Adoption. Discussion Paper Series EfD DP 09-15. Environment for Development. Addis Ababa, Ethiopia. $21 \mathrm{pp}$.

Sodjinou E., Glin L., Nicolay G., Tovignan S. and Hinvi J. 2011. Socioeconomic determinants of organic cotton adoption in Benin, West Africa. Agricultural and food economics, 3 (12):1-22. DOI 10.1186/s40100-015-0030-9

Solomon Asfaw, Bekele Shiferaw, Simtowe F. and Lipper L. 2012. Impact of modern agricultural technologies on smallholder welfare: evidence from Tanzania and Ethiopia. Food Policy, (3): 283-95. http://dx.doi.org/10.1016/j.foodpol.2012.02.013 
Solomon Asfaw, Bekele Shiferaw, Simtowe F. and Mesisa Hagos. 2011. Agricultural technology adoption, seed access constraints and commercialization in Ethiopia. Journal of Development and Agricultural Economics, 3: 436-47.

Sosina Bezu, Girma Tesfahun, Bekele Shiferaw, and Ricker-Gilbert J. 2014. Impact of improved Maize adoption on welfare of farm households in Malawi: World Development, 59:120131. http://dx.doi.org/10.1016/j.worlddev.2014.01.023.

Spielman D., Dawit Kelemework, and Dawit Alemu. 2012. Seed, Fertilizer, And Agricultural Extension In Ethiopia. In Food and Agriculture in Ethiopia: Progress and Policy Challenges, Edited by Paul A. Dorosh and Shahidur Rashid, 41. Philadelphia: University Of Pennsylvania Press. 41 pp.

Stacks D. and Salwen M. 2014. An integrated approach to communication theory and research. Second edition. Routledge.

Storck H., Bezabih Emana, Berhanu Adnew, Browiecki A. and Shimelis W/Hawariat.1991. Farming systems and Farm Management Practices of Small holders in the Hararghe Highlands. Farming system and resource Economics in the Tropics. 11: Wissenschafts Varlag Vauk Kiel KG, Germany.

Straub E. 2009. Understanding technology adoption: theory and future directions for informal learning. Review of Educational Research, 79: 625-49.

Tadele Tafese. 2016. Adoption and Intensity of row seeding in the case of Wolaita Zone. Open Access Library Journal, 3 (03): 1-12. http://dx.doi.org/10.4236/oalib.1102443.

Taherdoost H. 2018. A review of technology acceptance and adoption models and theories. In 11th international conference interdisciplinary in engineering. Procedia Manufacturing (22): 960-967. https://doi.org/10.1016/j.promfg.2018.03.137

Tariku Bezabih. 2012. Study on the Intensity and Adoption of Improved Wheat Varieties and Associated Agronomic Practices in Kaffa Zone, The Case of Gesha Woreda. MSc Thesis, Indira Gandhi National Open University, India. 138 pp. 
Tegegn Daniel. 2013. The District Stakeholders' Perception towards Improved Wheat Technologies Delivered to Smallholder Farmers: The Case Study in Chencha District in Gamo Gofa Zone, Ethiopia. MSc Thesis. Van Hall Larenstein University of Applied Sciences, Netherland. 70 pp.

Tesfaye Solomon, Ayele Tessema, and Adam Bekele. 2014. Adoption of improved wheat varieties in robe and Digelutijo districts of Arsi zone in Oromia region, Ethiopia: A double-hurdle approach. African Journal of Agricultural Research, 9 (51): 3692-3703.

Tesfaye Zegeye, Girma T, Tanner D, Verkuijl H, Aklilu Agidie, Mwangi W. 2001. Adoption of Improved Bread Wheat Varieties and Inorganic Fertilizer by Small Scale Farmers in Yelma Dansa and Farta Districts of Northern Ethiopia. Mexico, D.F. Ethiopian Agricultural Research Organization (EARO) and International Maize and Wheat Improvement Center (CIMMYT), $42 \mathrm{p}$.

Uaiene R., Arndt C. and Masters W. 2009. Determinants of agricultural technology adoption in Mozambique. Discussion papers 67. National Directorate of Studies and Policy Analysis, Ministry of Planning and Development, Republic of Mozambique.

Venkatesh V. and Davis F. 2000. A theoretical extension of the technology acceptance model: Four longitudinal field studies. Management Science, 46(2): 186-204.

Warmbrod J. 2014. Reporting and Interpreting Scores Derived from Likert-Type Scales. Journal of Agricultural Education, 55 (5): 30-47. Doi: 10.5032/jae.2014.05030

Wooldridge J. 2002. Econometric analysis of cross section and panel data. Cambridge. The MIT Press, Cambridge, Massachusetts, London, England.

Worku Mentire and Yishak Gecho. 2017. Factors affecting adoption of wheat row planting technology: The case of Sodo Zuriya Woreda, Wolaita Zone, Southern Ethiopia. Innovative Systems Design and Engineering, 8 (1):1-8.

Yamane T. 1967. Statistics: An Introductory Analysis. Second edition. Harper and Row. New York, 919. 
Yassin Ismael, Adam Bekele and Mengistu Ketema. 2016. Determinants of level of smallholder farmers participation in Potato sales in Kofele District, Oromia Region, Ethiopia. Journal of Agricultural Science and Research, 3 (2): 23-30.

Yigezu Atnafe, Mugera A., El-Shater T., Aw-Hassan A., Piggin C., Haddad A., Khalil Y. and Loss S. 2018. Enhancing adoption of agricultural technologies requiring high initial investment among smallholders. Technological Forecasting \& Social Change, 134:19906. https://doi.org/10.1016/j.techfore.2018.06.0

Yu B., Nin-Pratt A., Funes J., and Sinafikeh Asrat. 2011. Cereal Production and Technology Adoption in Ethiopia. Ethiopia Strategy Support Program II (ESSP II). ESSP II, Working Paper 31. The International Food Policy Research Institute (IFPRI). Addis Ababa, Ethiopia. $36 \mathrm{pp}$.

Zerihun Nigussie, Getachew Alemayehu, Enyew Adgo, Yoseph Tewodros and Freyer B. 2016. Reasons for acceptance of improved potato varieties by smallholder producers. International Journal of Vegetable Science, 22 (4): 346-352.

Zewdie Bishaw and Dawit Alemu. 2017. Farmers' perceptions on improved bread wheat varieties and formal seed supply in Ethiopia. International Journal of Plant Production, $11(1): 117-130$.

Zewdie Bishaw, Struik P. and Van Gastel A. 2010. Wheat seed system in Ethiopia: Farmers' varietal perception, seed sources, and seed management. Journal of New Seeds, 11(4): 281-327, DOI: 10.1080/1522886X.2010.518302. 


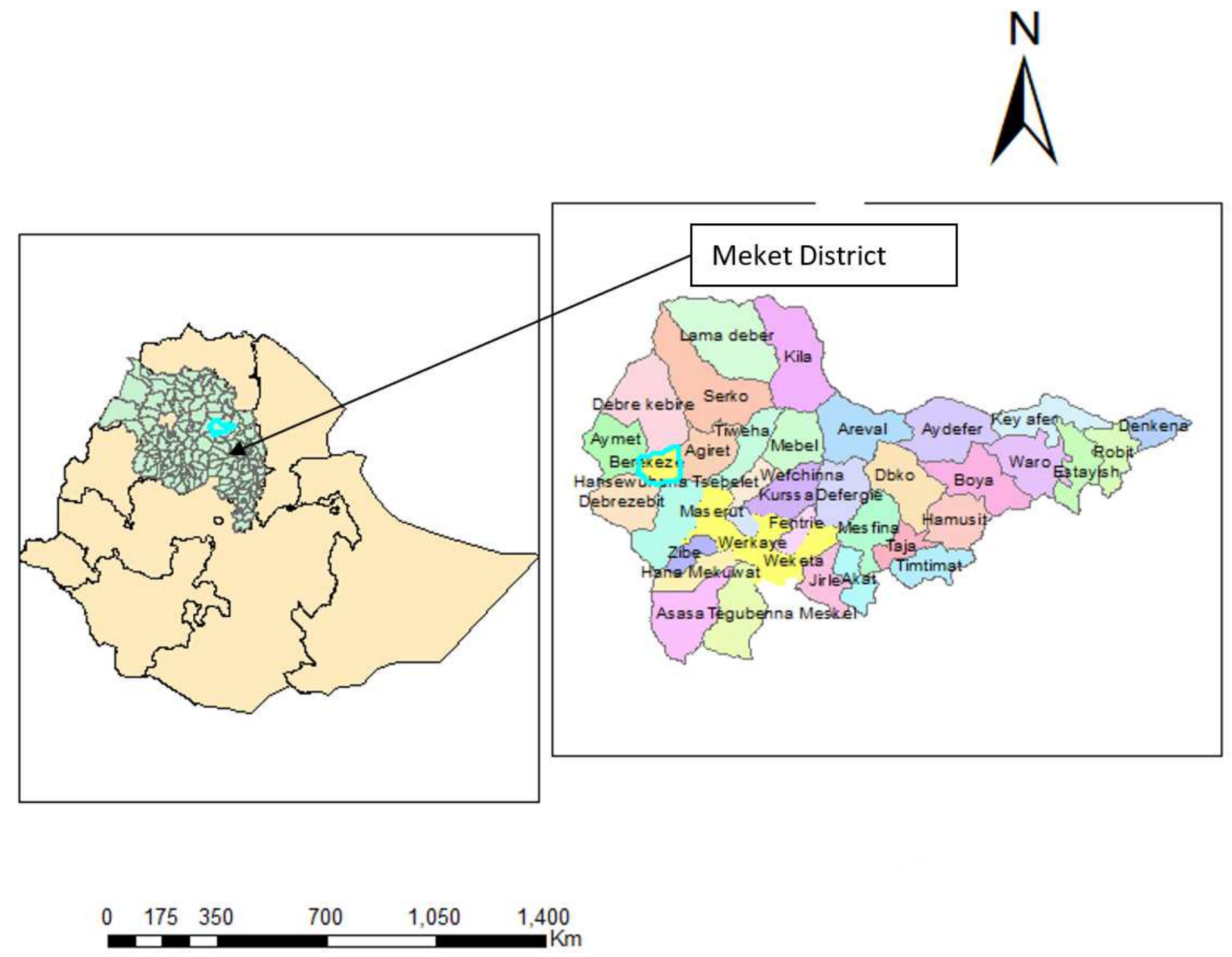

Figure 1

Location map of the study area 